\title{
ANTÔNIO VIEIRA: A PALAVRA EMPENHADA
}

Silvana Maria Pessôa de Oliveira Universidade Federal de Minas Gerais

O céu estrela o azul e tem grandeza. Este, que teve a fama e à glória tem, Imperador da língua portuguesa, Foi-nos um céu também.

(Fernando Pessoa)

\section{A Retórica}

$\mathbf{N}$ a Grécia clássica, a retórica tem como objeto o estudo das técnicas de argumentação não coerciva, cuja meta é legitimar juízos e, com isso, ganhar ou reforçar o assentimento dos ouvintes. De acordo com essa tradição, a retórica se propõe a persuadir, ganhar a adesão alheia, por meio de uma argumentação convincente. Chaïm Perelman - filósofo que se empenha em pensar a retórica nas suas relações com a linguagem, com a lógica e com o conhecimento em geral, resgatando-a da dimensão de ornato e decoração lingüística a que fora relegada define a retórica como o estudo dos recursos de argumentação que permitem obter ou aumentar a adesão das mentes às teses que se lhes apresentam ao assentimento. A ciência retórica concerne, pois, não ao verdadeiro, mas ao plausível, e a adesão do homem não é simplesmente submissão, mas decisão e participação. Como a argumentação nunca é coerciva, pode-se perguntar em que medida uma tentativa de argumentar em favor de uma tese se arrisca, ao contrário, a abalar a confiança que se tem nela. E efetivamente o fato de se discutir a reputação de um homem prova que ela é discutível, que não está livre de questionamento. Assim é que, quando Vieira discute com Deus, chamando-lhe desatento e distraído, o pregador 
não faz mais que usar certas técnicas de argumentação, ou seja, parte de uma premissa considerada absurda para, dessa maneira, colocar em questão a autoridade divina, ao assentar Deus no banco dos réus, acusando-o de omisso.

Uma vez que visa à adesão, a argumentação retórica depende essencialmente do auditório a que se dirige, pois o que será aceito por um auditório não o será por outro; e isso diz respeito não só às premissas do raciocínio, mas também a cada elo deste e, enfim, ao próprio juízo que será baseado no todo da argumentação. Portanto, se o objetivo do retor é ganhar a adesão do auditório, qualquer argumentação, para ser eficaz, deve apoiar-se em teses admitidas pelo auditório. Com efeito, o que caracteriza o ponto de vista retórico é a preocupação fundamental relativa às opiniões e aos valores do auditório a que se dirige o orador e, mais particularmente, no que se refere à adesão desse auditório a cada uma das teses invocadas pelo orador. Essa adesão é conseguida através de um dos recursos caros à retórica: o uso da persuasão. Para os retores, persuadir é mais do que convencer: a persuasão acrescentaria à convicção a força necessária que é a única que conduzirá à ação. Convencer, seria, pois, uma primeira etapa - o essencial é persuadir, ou seja, abalar a alma para que o ouvinte aja em conformidade com a convicção que lhe foi comunicada. É por isso que a persuasão, exerça-se ela pela fala ou por escrito, supõe um auditório - aqueles que se procura persuadir. No diálogo intitulado "Fedro", Platão sonha com uma retórica cujos argumentos poderiam convencer os próprios deuses. Também no "Sermão pelo bom sucesso das armas de Portugal contra as de Holanda", Vieira persegue exatamente o mesmo objetivo: persuadir Deus a combater pelos portugueses contra os holandeses. É interessante notar que a definição que Platão dá do dialético é coincidente, em muitos pontos, com a do retor. Ambos, dialeta e retor, são concebidos como quem sabe interrogar e responder, aqueles que são capazes de provar as teses formuladas pelo interlocutor e de refutar as objeções que se opõem às suas; é o espírito crítico que dá provas de seu domínio sobre a matéria em discussão, ao questionar os outros e ao fornecer respostas 
satisfatórias às suas perguntas. Contrariamente ao filósofo, porém, que educa para contemplar, o retor se esmera em educar para agir. Nesse sentido, Vieira encarna, à perfeição, o ideal do retor e do sophistés, que indica não o simples orador, mas o orador que dá espetáculos, que oferece audições públicas.

Nesse trabalho, uso os termos retor e orador como sinônimos. Entendo por retor ou ou orador quem apresenta a argumentação, seja oralmente ou por escrito; entendo por auditório todos aqueles a que visa a argumentação, sejam eles ouvintes ou leitores. Cumpre observar ainda que, se uso os termos "orador"e "auditório" é por mera comodidade de expressão, e que se devem englobar sob essas palavras todos os modos de expressão verbal, ou seja, tanto a fala quanto a escrita.

\section{Vieira e os Sermões}

Etimologicamente, a palavra sermão deriva do latim sermone, que quer dizer conversação. Essa derivação remete a um aspecto importante da arte de pregar vieiriana: a sua natureza eminentemente retórica, pública, persuasiva. O discurso de Vieira - à época, normalmente proferido do púlpito, a partir de um texto bíblico -, pretende conter a verdade de uma tradição compartilhada. Exemplo de sedutora argumentação, produto de um árduo e incessante trabalho com a linguagem, o sermão dirige-se a um auditório particular, numa circunstância conjuntural precisa, em determinada situação.

É próprio do sermonista tentar persuadir, obter a adesão da platéia, graças a uma bem conduzida argumentação. É como se ele pretendesse que o ouvinte pensasse: "esse homem é tão extraordinário, é a voz de Deus, eu tenho que me elevar, continuar perto da religião, cultivar-me para chegar perto de Deus". Nesse sentido, o sermão torna-se um lugar privilegiado:por meio dele, a palavra de Deus se revela ao mundo e se faz História.

É interessante notar que, num primeiro nível de leitura, o discurso de Vieira parece ser, na maioria das vezes, monológico. 
Tem-se a impressão de que mesmo quando ele faz perguntas ao público são perguntas vazias. Contudo, se se observa mais atentamente esse discurso, é possível perceber a existência de uma interlocução inererente ao sermão; essa dialogia está ligada ao fato de que ele - como toda argumentação - visa a uma mudança, aspira a criar ou a aumentar o assentimento da platéia à tese proposta. Não se trata apenas de transmissão de informações ou de conhecimento; em última instância , visa-se à ação, pois se está no domínio da razão prática, da "práxis" política. O persuadido, ao dar seu asssentimento, muda de atitude, modifica seus valores. E essa mudança está diretamente relacionada à ação. É dessa maneira que a aparente voz monológica dos sermões vieirianos pode ser intrinsecamente dialógica. Eduardo Prado Coelho chama a atenção para o fato de que, na concepção de Bakhtin, não há enunciado sem réplica, nem enunciado que não seja a réplica para um enunciado anterior. A própria voz impõe uma forma dialógica: alguém comunica alguma coisa a alguém. A enunciação é o produto da interação entre dois interlocutores: a palavra é apenas o território precariamente comum entre o emissor e o receptor e, por isso, cada palavra é dupla, e às vezes, dúplice. Não há discurso monológico. É por isso que, freqüentemente, o discurso do jesuíta português centra-se no auditório, ou seja, no leitor; mesmo que esse auditório esteja aparentemente mudo, ele representa a potencialidade da resposta:

É cousa tão natural o responder, que até os penhascos duros respondem; e para as vozes têm ecos. Pelo contrário, é tão grande violência não responder, que aos que nasceram mudos fez a natureza também surdos; porque, se ouvissem e não pudessem responder, rebentariam de dor. ${ }^{1}$

A existência do auditório torna-se, então, de fundamental importância. Muitas vezes ele pode até funcionar como uma espécie

${ }^{1}$ VIEIRA, Carta aos padres do Colégio da Bahia, 1694. Apud CIDADE, Padre Antônio Vieira. p.78. 
de personagem do sermão. Em Vieira - professor de retórica no Colégio de Olinda e formado na Escolástica seiscentista, cultora da dialética pela dialética -, o interlocutor é sempre um co-locutor, embora possa permanecer silencioso, aparentemente apenas na condição de ouvinte:

Nas cores que o auditório mudava, bem via eu claramente os afetos que por meio destas palavras Deus obrava nos corações de muitos, os quais logo ali saíam persuadidos a se querer salvar, e a aplicar os meios que para isso fossem necessários a qualquer custo. $^{2}$

O sermão é, portanto, uma prática interacional, cuja pregação está longe de ser uma mera manifestação das técnicas e habilidades da locução ou uma exibição simplesmente espetacular. Ou melhor: ele demanda, ainda, diferentes atores que interagirão em determinada situação; daí ele se caracterizar por possuir uma especificidade não apenas porque se distingue de outros tantos gêneros, mas porque tem virtualidades que singularizarão cada pregação, tais como local, voz do pregador, momento da enunciação, etc.

Não é por acaso que, de modo geral, o sermão tem uma destinação profana; de composição singular em sua origem (integra elementos transcendentais e conjunturais), volta-se para auditórios, comportamentos, fatos que são elementos da história humana e não da divina. Ele tem uma vocação para o externo, para a exposição pública, para a eficácia política, para a modificação de uma situação anterior, para a invocação da participação da platéia. Nesse sentido, o sermão é uma forma de saber e poder, conjugados. A visibilidade do poder do púlpito se dá pela articulação entre fontes de poder internas ao texto, à maneira de pregar, à cena da locução. A eficácia histórica da pregação se medirá pela possibilidade de mobilização dos ouvintes obtida por esta conjugação de fontes de poder. Tratase do sermão concebido como ideologia da ação. O vínculo estabelecido entre palavra e ação, a idéia de que um discurso bem

${ }^{2}$ VIEIRA, Cartas, tomo I, p. 339 Apud CIDADE, Padre Antônio Vieira, p.132. 
organizado garante o êxito da ação, faz supor a existência de um "projeto". O projeto é, com efeito, uma construção verbal que precede a realização de algo. A conformidade do projeto com as normas do discurso prefigura a conformidade da ação com a realidade - condição de seu sucesso.

E qual seria esse projeto vieiriano? É evidente que Vieira sacerdote jesuíta e confessor de reis - reforça o papel mediador da Igreja, representado modelarmente pelos missionários da Companhia de Jesus, cuja missão é essencial para a organização da monarquia católica universal e a sustentação do império português do século XVII. Um de seus principais objetivos é o reforço das missões jesuíticas como condição do êxito da ação espiritual da Igreja e do fortalecimento político do Estado português. Resulta disso o extraordinário papel missionário da Companhia de Jesus no cumprimento do plano salvífico da Providência, tanto para a história do Império, quanto para as almas individuais dos homens.

Vieira acentua sobremaneira o papel missionário de Portugal no mundo: cabe a esse país, mais que a qualquer outra nação cristã, avançar sobre os "gentios" e reduzi-los à Cristandade. Cabe definitivamente, porque os descobrimentos são, para ele, acima de tudo, matéria sacra. A Companhia de Jesus torna-se corpo místico e político, ao qual foi dada a missão particular de propagação da fé católica no Novo Mundo. Sob essa perspectiva, Vieira postula uma espécie de conciliação entre a consciência cristã e as práticas de eficácia temporal. Daí, a freqüente mistura de religião e negócios em seus sermões. É significativa em Vieira essa prática, que procura acomodar aspectos temporais e espirituais, ao evidenciar os frutos histórico-políticos advindos da correta semeadura ético-religiosa.

Dessa forma, é fácil observar, em Vieira, a impossibilidade de traçar limites rigídos entre as vias temporal e espiritual - para o sermonista, o bem comum do governo, da monarquia, é análogo ao projeto de salvação da comunidade religiosa, numa estranha combinação que une o rebanho de Cristo e o corpo do Estado. 


\section{O Púlpito como Palco e Arena}

Sem dúvida, o púlpito é o lugar da teatralização do discurso. Esse discurso privilegia o plástico e o sensorial, o que faz do discurso e do púlpito algo para ser visto e ouvido. Com efeito, o púlpito é um palco, palco esse tão mais valorizado quando se sabe de sua proeminência nas igrejas barrocas, o que possibilita a criação de todo um clima de encenação. Nesse sentido, a própria igreja barroca é uma máquina teatral, que aciona o ver e o ouvir. Há uma passagem interessante que apresenta essa dramatização de modo explícito:

(...) e se esta representação vos não enternecer e tiverdes entranhas para o ver sem grande dor, executai-o embora. Finjamos, pois (o que até fingido e imaginado faz horror): finjamos que vem a Bahia e o resto do Brasil a mãos dos holandeses; que é o que há de suceder em tal caso? - Entrarão por esta cidade com fúria de vencedores e de hereges; não perdoarão a estado, a sexo nem a idade; com os fios dos mesmos alfanges medirão a todos. ${ }^{3}$

Na Idade Média, o ouvido é o sentido mais desenvolvido e sua primazia era teologicamente garantida: a Igreja baseia sua autoridade na palavra, pois a fé é audição. Não é sem razão que Lutero afirma que o ouvido é o órgão de Cristo. Mais tarde, há uma inversão: os olhos tornam-se os principais órgãos da percepção. Ignácio de Loyola, nos Exercícios Espirituais modifica essa hierarquia dos cinco sentidos, ao eleger a imagem como matéria constante dos exercícios. Assim, as representações, as alegorias, as pequenas narrativas evangélicas transformam-se em unidades constitutivas da meditação e da ortodoxia. Por essa razão, o Barroco é conhecido como arte da coisa vista e Vieira torna-se mestre em fazer com que os ouvidos vejam:

Entremos e vamos examinando o que virmos por parte. Primeiro que tudo vejo cavalos, liteiras e coches: vejo criados de diversos calibres, uns com librés, outros sem elas: vejo galas, vejo jóias, vejo baixelas: as

3 VIEIRA, Sermão pelo bom sucesso das armas de Portugal contra as de Holanda. p. 47-48. 
paredes vejo-as cobertas de ricos tapizes: das janelas vejo ao perto jardins, e ao longe vejo quintas; enfim vejo todo o palácio e também o oratório; mas não vejo a fé. E por que não aparece a fé nesta casa? Eu o direi ao dono dela. Se os vossos cavalos comem à custa do lavrador, e os freios que mastigam, as ferraduras que pisam, e as rodas e o coche que arrastam são dos pobres oficiais, que andam arrastados sem cobrar um real; como se há-de ver a fé na vossa cavalariça? ${ }^{4}$

O próprio Vieira, ao condenar o estilo dominicano de pregar, ao qual ele tacha de empeçado, dificultoso e afetado, assim se refere ao uso que os religiosos da ordem de São Domingos fazem do púlpito:

Uma das felicidades que se contava entre as do tempo presente era acabarem-se as comédias em Portugal, mas não foi assim. Não se acabaram, mudaram-se: passaram do teatro para o púlpito. ${ }^{5}$

É conhecido o fato de Vieira se posicionar contra o misticismo contemplativo dos dominicanos, que acham mais cômodo ficar na Metrópole e deslumbrar o público com a acrobacia dos sermões gongóricos. Ao contrário dos jesuítas - que concebiam o sermão como um combate - os dominicanos consideram o sermão uma espécie de espetáculo, visando ao prazer dos espectadores e à glória do autor, mediante a valorização das sutilezas de sua técnica. Para Vieira, o sermão pregado por dominicanos é uma comédia transferida do palco para o púlpito. O historiador José van den Besselaar relata que o púlpito era muitas vezes também um teatro, em Portugal. Muitas pessoas cultas iam às igrejas para ouvirem a pregação de um célebe orador, por não terem a possibilidade de assistirem a uma representação teatral. Não raro havia rivalidades abertas entre os famosos pregadores da época, circunstância picante que enfatizava ainda mais o caráter mundano da pregação.

Por outro lado, a figura do pregador nas igrejas barrocas é centralizadora e indica a autoridade que esse pregador possui. É ele

\footnotetext{
${ }^{4}$ Sermão da Quinta Dominga da Quaresma. Apud BOSI, Dialética da Colonização, p.131.

${ }^{5}$ VIEIRA, Cartas. Apud Antônio Sérgio. Ensaios. vol.V. p. 99.
} 
que detém o poder da palavra, conhece o texto bíblico e funciona como agregador do grupo, fortalecendo-o e conduzindo-O. Como orador, sua posição é destacada; o púlpito é seu posto de observação. É ele que tem acesso exclusivo ao púlpito, cuja proeminência arquitetônica sobreleva o papel dele como sacerdote; é dele a escolha pensada e anterior do trecho do Evangelho a ser lido; e dele, as vestes características e singulares. Estabelece-se, portanto, entre o sermonista e o público uma relação desigual. Não por acaso, a distância entre púlpito e público torna-se uma barreira que separa o detentor da fala e seus ouvintes.

O sermonista usa e abusa dos poderes da argumentação: utiliza uma linguagem que privilegia certos efeitos sensíveis para, assim, persuadir o ouvinte pela voz, pelo ritmo, pelas figuras de linguagem e pelos gestos. O pregador tem um objetivo prático em vista: para conseguir a adesão do ouvinte, recorre a todos os meios de expressão e de enredo. A intenção é discutir para convencer e em seguida, converter, influindo no espírito dos ouvintes através do recurso a imagens ousadas e ao jogo de trocadilhos. O sermonista, como um bom retor, não obriga, nem impõe: persuade. Alcir Pécora chama a atenção para o fato de que Vieira trata a pompa do cerimonial da missa exatamente da mesma forma que a ornamentação retórica, pompa lingüística em que se prepara o impacto da conversão. Tais pompas parecem adequar-se perfeitamente a esse teatro da fé. A tribuna representa o poder da linguagem. Nesse palco retórico, a razão vieiriana é basicamente argumentativa e persuasiva, retórica e política, e o discurso se mostra na sua faceta de litígio e combate, espetáculo e drama.

\section{Referências Bibliográficas}

PÉCORA, Alcir. Vieira, o índio e o corpo místico. In: NOVAES, Adauto. (org.) Tempo e bistória. São Paulo: Companhia das Letras, 1992. p. 423-461.

PÉCORA, Alcir. Teatro do sacramento. São Paulo: EDUSP/PONTES, 1994. 
FLORES, Luiz Filipe Baeta Neves. Palavra, mito e história no sermão dos sermões do Padre Antônio Vieira. In: RIEDEL, Dirce Cortes. Narrativa - ficção e história. Rio de Janeiro: Imago, 1988. p. 170186.

SARAIVA, António José e LOPES, Óscar. História da literatura portuguesa. Porto: Porto Editora, s/d.

ECO, Umberto. A estrutura ausente. São Paulo: Perspectiva, 1984.

BOSI, Alfredo. Vieira ou a cruz da desigualdade. In: Dialética da colonização. São Paulo: Companhia das Letras, 1992. p. 119-148.

CIDADE, Hernâni. Padre Antônio Vieira. Lisboa: Editorial Presença, 1985.

PERELMAN, Chaïm. Retóricas. Trad. Maria Ermantina Galvão Pereira. São Paulo: Martins Fontes, 1997.

\section{Resumo}

Este trabalho visa a refletir sobre a arte de pregar vieiriana, a fim de discutir os principais eixos articuladores dessa prática. Serão enfocados os seguintes elementos: a) a retórica como técnica argumentativa que visa à persuasão; b) Antônio Vieira enquanto retor e dialeta; c) o sermão como prática interacional; d) Antônio Vieira como porta-voz da monarquia lusitana; e) o púlpito como palco e arena.

\section{Résumé}

Ce travail a comme objectif la reflexion sur l'art vieirienne de prêcher, pour qu'on puisse établir les principaux axes articulateurs de cette pratique. Les éleménts ci-dessous seront anvisagés: a) La rhétorique comme technique argumentative qui tend à la persuasion; b) Antônio Vieira comme rhéteur et sophistés; c) Le sermon comme pratique intéractionnelle; d) Antônio Vieira comme porte-voix de la monarchie lusitaine; e) La chaire comme scène et arène. 